\title{
Psalms in the Book of the Twelve: How Misplaced Are They?
}

\author{
Erhard S. Gerstenberger
}

\section{Paradigm Switches within the Study of the Hebrew Scriptures}

Like other layers of the Old Testament tradition, the prophetic writings in the Hebrew Scriptures are undergoing new investigations because the modern exegete's style of living, thinking, and questioning has dramatically changed over the past decades. ${ }^{1}$ Alterations in the reader's perspective and living conditions, according to any self-critical hermeneutical theory, necessarily result in fresh reconstructions of our own concepts of past history and theology. The Hebrew canon of three "large" and twelve "minor" prophets, being an important part of the TaNaK (Torah; Nebiim; Ketubim) consequently needs to be scrutinized almost from scratch in regard to composition, form- and tradition history, the profile of possible authors and transmitters, possible life-situations, and many other points of view. The results of such endeavors are amazing. They confront us with unfamiliar visions of the growth and use of prophetic literature within the social texture of exilic/post-exilic communities in Judah and perhaps other regions. They also reveal a characteristic remolding of prophetic images by later tradition, a result that calls into question our traditional concepts of "classical prophecy."

\section{Liturgical Genres within the Prophetic Corpus}

As a case in point we focus on the abundance of liturgical genres within the prophetic writings. It seems strange, indeed, that most of the fifteen prophetic books in the Hebrew Bible contain examples of what we may call psalmic genres, be they more on the side of purely "liturgical" and "hymnic" or else of "homiletical"" categories of text. Setting aside the latter for

1 To cite but one effort of a fundamental reevaluation of the prophets and prophecy: Ferdinand E. Deist, "The Prophets: Are We Heading for a Paradigm Switch?" BZAW 185 (1989) 1- 18.

2 Note this truly Protestant distinction between altar and pulpit, so to speak, or between fixed agendaric and more spontaneous parts of worship. Some scholars have already investigated prophetic texts under liturgical and homiletical perspectives; cf. Eberhard 
the time being, we notice a wealth of passages which seem to belong to worship agendas, both in the form of unilateral prayers (i. e. prayers oriented from people to God) and of hymns sung in praise of Yahweh, both polyphonic and antiphonic (in a strictly "liturgical" shape), as a proclamation to and response of the community at hand. Thus we find almost fullscale communal complaints in Jer 14:2-14; Isa 63,7 - 64:10; Joel 1 - 2, while e.g. Hos 6:1-3; 14:3-4 apparently are fragments of more extensive collective prayers. The so-called "individual complaints" are at least mirrored in the "Confessions of Jeremiah" (Jer 11:18-22; 12:1-6: 15:10-21; $17: 12-18 ; 18: 18-23 ; 20: 7-18)$. A full individual thanksgiving song is placed into narrative contexts (Isa 38; Jon 2), while a communal variety comes up in the "Isaiah Apocalypse" (Isa 26:1-6). Regular hymns or passages reminiscent of praise show up here and there, sometimes marking the end of collected sayings (cf. Isa 42:10-12; Hab 3; Zeph 3:14-20). ${ }^{3}$ All in all, this phenomenon calls for fresh attention and explanation: Have these psalmic elements been placed in the context of prophetic utterances and discourses by mistake? Or imagining the opposite extreme: do the liturgical components constitute the original matrix of communal interaction out of which have grown prophetic sayings and speeches?

\section{History of the Research on Liturgical Components in Prophetic Corpora}

The question just posed runs counter, of course, to everything we had been led to believe about prophets and prophetic utterances in biblical contexts. In contrast with anonymous, liturgical beginnings, we traditionally prefer a different anchoring of prophetic speech. One of the firmly entrenched and most influential views of prophetic activity through the $19^{\text {th }}$ and $20^{\text {th }}$ centuries has been that of personal identity and authorship of each individual messenger of God. Bernhard Duhm, for example, based his interpretation of

von Waldow, "Anlaß und Hintergrund der Verkündigung des Deuterojesja," (Ph. D. diss., Bonn 1953); Ernest W. Nicholson, Preaching to the Exiles (Oxford: Blackwells, 1970); Henning Graf Reventlow, Liturgie und prophetisches Ich bei Jeremia (Gütersloh: Gerd Mohn, 1963); William H. Bellinger, Psalmody and Prophecy (JSOTSup 27; Sheffield: JSOT Press, 1984). Also, Erhard S. Gerstenberger, "Höre, mein Volk, laß mich reden! (Ps 50,7)," BK 56 (2001) 21-25.

3 Hermann Gunkel and Joachim Begrich (Einleitung in die Psalmen [Göttingen: Vandenhoeck, 1933], 32-33) list a whole sequence of mostly brief prophetical passages classified as "hymns": Isa 6:3; 12:1-2, 3-6; 25:1, 5, 9; 30:18d; 40:12-17, 22-24, 26, 2829 ; 41:13; 42:5, 10-12; 43:1, 14, 15, 16-17; 44:2, 6, 23, 24-28; 45:6-7, 11, 15, 18; $46: 10-11 ; 47: 4 ; 48: 12,17,20 ; 49: 5,7,13 ; 51: 15,22 ; 52: 9-10 ; 57: 15 ; 61: 10-11 ; 63: 7$; Jer $2: 6 ; 5: 22,24 ; 10: 6-7,10,12-16 ; 31: 7,35 ; 33: 2 ; 51: 10,15-16$; Joel $2: 21,23 ;$ Amos $4: 13 ; 5: 8 ; 9: 5-6$; Nah 1; Hab 1:12-13; 3:18-19; Zeph 3:14-15; Sach 2:14; 9:9; $12: 1$. 
prophetic writings exclusively on the authenticity of prophetic personality. ${ }^{4}$ His lead has been followed by many Old Testament scholars. The historical figures named in superscriptions of prophetic books (and sometimes nowhere else!) were widely considered the authors of at least a nucleus of the respective writings. Disciples may have functioned as secretaries to these "men of God," but all later additions to their authentic "minutes" of divinely inspired kerygma were regarded as inferior or worthless, because they could not possibly match the genius of the prophetic mind and spirit, surpassing, as it were, by far the normal frame of contemporary conscience, experience and ethical standards.

This traditional, personalistic view by and large has been replaced by subsequent research with its changing hermeneutical parameters. One important moment in the shift certainly was the discovery of form criticism by Hermann Gunkel and Sigmund Mowinckel. The authors of biblical texts, especially of individual psalms, recede into the background. Instead, communicative situations are credited with the production of texts serving collective, i.e. communal, ends. Mowinckel in particular emphasized the thoroughly cultic character of the psalms. To his mind, temple servants and cultic singers composed the larger part of the psalms in the service of the temple community, and for collective use in worship. ${ }^{5}$

A second impetus for changing the traditional paradigm came from tradition-historical studies which reevaluated the formative forces shaping and inventing the inherited texts, be they orally transmitted or handed down in written form. Many exegetes today agree that considerably large parts of prophetic books have been molded (composed and_formulated) by transmitters and scribes in a long process of scriptural development. By the same token scholars today recognize that the image of prophets and prophecy has been at least partially if not completely formed by later interpretation. ${ }^{6}$ Set-

4 Cf. Bernhard Duhm, Die Theologie der Propheten als Grundlage für die innere Entwicklungsgeschichte der israelitischen Religion (Bonn: Marcus 1875); idem, Israels Propheten ( $2^{\text {nd }}$ ed.; Tübingen: J.C.B. Mohr, 1922).

5 Cf. Sigmund Mowinckel, Psalmenstudien III: Kultprophetie und prophetische Psalmen (Oslo: Kristiania, 1923; repr., Amsterdam: Schippers, 1961). He believed that the Prophets were cultic functionaries, yet theoretically free to communicate the word of God to the congregation using the first person of the deity.

6 To give but a few examples: Joseph Blenkinsopp freely admits the creative role of tradition in forming the biblical concepts of prophecy, e.g.: "It will now be apparent that those who edited and transmitted the book of Jeremiah over a period of several centuries, have been at pains to present him as fulfilling the paradigm of the prophetic role in Israel." Idem, A History of Prophecy in Israel $\left(2^{\text {nd }}\right.$ ed.; Louisville: Westminster John Knox, 1996), 135; cf. my own epilogue ["Ausblick"] to the German translation entitled Geschichte der Prophetie in Israel (Stuttgart: Kohlhammer, 1998), 266-289. The research done by scholars like A. Graeme Auld, Robert P. Carroll, David L. Petersen, 
ting aside, therefore, the idea of personal authorship of prophetic sayings, discourses, narratives - which certainly has had and further has its merits at some point - more and more interpreters are discovering the real depth dimensions of the prophetic traditions and the changes which went on through the centuries of Israelite and Judean history. Other parameters are also necessary in tracing this development. The growth of prophetic books and the understanding of their remote, "classical" eponyms cannot be pictured in terms of biographical, personalistic, historical factors, but has to be grasped within the whole context of group processes affecting the community of believers and worshippers that treasured and modulated that sacred heritage.

Taking into account, furthermore, anthropological and sociological research on prophetic phenomena around the world, considering in this light more intensively and less dogmatically biblical evidence itself, we may conclude, that the agents of later communal organization were indeed paramount in forming the prophetic messages as well as the concepts of prophecy in general, as they now are extant in the Scriptures. This means that it has been principally the needs, aspirations, sufferings of the early Jewish community that have brought forth the prophetic books, using, as it were, rather faint memories of "classical" prophecy in Israel. Further, very few, if any, "authentic" words coming from the $8^{\text {th }}$ and $7^{\text {th }}$ centuries B.C.E. have been preserved.

\section{Psalms in the Twelve}

Applying these new visions of prophecy to the Book of the Twelve and seeking psalm-like materials within the relevant writings, we will venture a rough purview and evaluation of the 82 printed pages in the Hebrew Bible according to Rudolf Kittel's edition, as well as the 96 pages of the Biblia Hebraica Stuttgartensia, provided by Karl Elliger. There is no claim, however, of being exhaustive at this time.

\section{A. Psalms with an Opening Formula}

From the outset it is clear that psalmic passages in the Book of the Twelve do belong to different genres, and they have been placed - if that is what happened to them - into their context in various ways. Some of them are

Ernest W. Nicholson, Robert R. Wilson, Ehud Ben Zvi, Bernhard Lang, Karl Friedrich Pohlmann and many others has paved the way for this kind of reassessment.

7 The literature in regard to biblical prophecy is too extensive to be recited at this point, cf. instead John H. Hayes, "Prophecy and Prophets, Hebrew Bible," DBI 2:310-317; Klaus Koch, "Propheten / Prophetie II. In Israel und seiner Umwelt," TRE 27, 477 499. 
highlighted by some kind of opening formula. Jonah 2:2 (RSV v. 1), on account of its context, is a narrative introduction: "Then Jonah prayed to Yahweh, his God, from the belly of the fish." It is followed by the formulaic expression "he said" (cf. Isa 38:9 ["I said"]; 1 Sam 2:1; Exod 15:1; Judg 5:1 etc.). Clearly, this is a case of inserting a narrative (oral or written, literary) psalm, ${ }^{8}$ a thanksgiving song, to serve the plot of the story. Regardless of whether there are any liturgical implications in the position of such psalms, each inset text is entirely dependent on the use of the surrounding narrative. There are, in any case, no hints of the participation of worshippers intoning a song like this. The book of Jonah is the only true narrative text among the Twelve. Hence, it may be worthwhile to investigate more fully the rationale of its being there in the midst of so much prophetic proclaiming and preaching.

A second, and quite different, example of formal citation of a psalm is offered by Hab 3:1: "A prayer (תפלה) of the prophet Habakkuk according to šigyonot (שגינות)." This phrase is strongly reminiscent of redactional superscriptions, attributing a poem to some traditional singer, like Asaph, Korah, or David. In this case Habakkuk the nabi' is named the author or performer of the psalm, two details unknown in the Psalter. ${ }^{9}$ The term שגינות, on the other hand, appears in a similar form in the headline of Psalm 7 (שגינ לדוד), while the designation "prayer" is part of five psalmic superscriptions (Pss 17; 86; 90; 102; 142). Furthermore, psalmic annoלמנצח tations do conclude the Habakuk text. The last two words are ל"To the leader, with my stringed instruments"; cf. Pss 4:1; 6:1; $54: 1 ; 55: 1 ; 61: 1 ; 67: 1 ; 76,1)$. Thus, the psalm in Habakkuk is framed by elements which we know from superscriptions to Psalms. But how do we interpret this fact? Apart from the basic issue of how the superscriptions in the psalms may have worked, we ask: have parts of prophetic books been used in worship contexts, have they acquired a liturgical frame and then been inserted again into the original collection of prophetic sayings? Or has the psalm Habakkuk 3, a kind of theophanic victory song, attracted the discourses of Habakkuk $1-2$ ?

From the beginning the liturgical frame featured an author's name, even specifying that the poet was a "prophet." So the psalm may have provided the prophetic identity for the whole book. Be it as it may, modern interpre-

8 Cf. James W. Watts, Psalm and Story (JSOTSup 139; Sheffield: Academic Press, 1992).

9 The only occurrences of the name Habakkuk are in Hab $1: 1 ; 3: 1$. The designation nabi' appears three times in the Psalter, but never as an author: Ps 51:2 refers to the prophet Nathan, and Pss 74:9; 105:15 mention prophets of Yahweh in general. 
tations vary greatly. Some experts follow the track that later readers of the prophetic writings may have extracted opportune texts, i.e. psalm-like prophetic sayings, from that tradition and remodeled them for use in worship service. ${ }^{10}$ The Qumran Psalm tradition may be cited in support of this theory, but any relocation of the amended (liturgized!) version into the prophetic book remains enigmatic. Another hypothesis fully recognizes the liturgical provenance of Habakkuk 3 and makes the author a cultic prophet firmly anchored in the temple institution. ${ }^{11}$ If the prophet really had been a liturgical leader of a temple community, then his message as a whole would have featured cultic traits and contents. For some scholars, consequently, the book of Habakkuk reveals a perfectly liturgical structure of prophetic complaint being answered by God. The text of Habakkuk itself this way becomes proof of the much-conjured institution of cult prophecy. ${ }^{12}$

The crux of this theory, however, is that it has to leave behind the conception of the prophets as free-lance divine messengers, so dear to the main stream of relevant research. If prophets are held responsible for cult liturgies in the prophetic writings as well as the Psalter, they hardly can remain spontaneous critics of social, political and religious conditions in Israel. They in fact become cult officials and functionaries. More serious, to my mind, and instrumental to that erroneous interpretation is the fact that this representation of prophecy (although recognizing correctly the liturgical character of some texts) still clings to outmoded views of an objective, author-to-audience relationship with textual creativity belonging to the author-speaker alone. The creative stimulus of communal action, in this case of corporate worship, does not enter into consideration at all. If, on the contrary, scholars would admit diverse forms of free mediation between people and God and perhaps some institutionalized ways of communication with the divine, and if scholars learned to consider all systematizing concepts of prophecy to belong to later periods of Israel's spiritual history, then the diverse phenomena might fall into place.

10 Thus, e.g. Wilhelm Rudolph, Micha, Nahum, Habakuk, Zephanja (KAT XIII,3; Gütersloh: Gerd Mohn, 1975) 239-43.

11 Cf. e.g. Friedrich Horst and Theodor H. Robinson, Die Zwölf kleinen Propheten (HAT I,14: Tübingen: J.C.B. Mohr 1954), 183-186; Jörg Jeremias, Kultprophetie und Gerichtsverkündigung (WMANT 35, Neukirchen-Vluyn: Neukirchener Verlag 1970), 85-100.

12 Besides Jeremias, Kultprophetie und Gerichtsverkündigung, 99-100 n. 11, cf. Aubrey R. Johnson, The Cultic Prophet and Israel's Psalmody (Cardiff: University of Wales Press, 1979). Erhard S. Gerstenberger, "Psalm 12: Gott hilft den Unterdrückten. Zum Thema Kultprophetie und soziale Gerechtigkeit in Israel," in B. Jendorff und G. Schmalenberg, Anwalt des Menschen (Giessen: Fachbereich 07 der Justus Liebig Universität, 1983), 83-104. 
The smallest of all prophetic writings within the Twelve is Obadiah, comprising only 21 verses, which partly coincide with Jer 49:9, 14-16. Biblical tradition does qualify these divine "threats against Edom" as typically prophetic utterances, namely, as a "vision" (חזון) of the spokesman of Yahweh. ${ }^{13}$ Seemingly, therefore, the genre "oracle against foreign nations" does not belong into the liturgical fold. Nevertheless, we may still surmise that such oracles have been used in worship situations as a means of Israel's self defense against foreign domination. ${ }^{14}$ Furthermore, communal complaints in the Psalter do incorporate threats and curses against enemy nations and the oppressive rule of foreign powers (cf. Pss $60 ; 83 ; 137$ ). Interestingly enough, all three psalms just referred to mention the neighboring rival Edom, besides other nationalities. We have good reason, therefore, to include oracles against foreign nations into the repertoire of liturgical texts. The little book of Obadiah, consequently, constitutes a prime example of agendaric material being placed between (or cut out from) Amos and Jonah, emphasizing salvation for Israel through destruction of Edom. Obadiah gained book status by a special headline, extremely short as it may be (v. 1, the first six Hebrew words). Nevertheless, it seems that the booklet acquired an important liturgical function in the context of the Twelve.

\section{B. Psalms with no Opening Formula}

There are, by contrast, psalm-like passages in the Book of the Twelve that stand out without being formally separated from their contexts by formulaic introductions or subscriptions. One example is Joel 1:2 $-2: 27 .^{15}$ Some

13 "Vision" as a typical communication to messengers of Yahweh is used widely, especially in exilic/post-exilic prophetic texts; cf. Isa 1:1; Jer 14:14; 23:16; Ezek 7:26; 12:22-27; Hos 12:11; Mic 3:6; Nah 1:1; Hab 2:2-3, and heavily concentrated in Dan 8.

14 The genre and Sitz im Leben of these particular "oracles" have not been sufficiently studied so far. Cf. Peter Höffken, "Untersuchungen zu den Begründungselementen der Völkerorakel des Alten Testaments," (diss., Bonn, 1977); Bernhard Gosse, Isaie 13,1 14,23 dans la tradition littéraire du livre d'Isaie et dans la tradition des oracles contre les nations (OBO 78; Fribourg and Göttingen: University Press and Vandenhoeck, 1988); Joseph Blenkinsopp, Prophecy in Israel, 131-132; 175-176 et passim. Scholars in general agree on the exilic/post-exilic dates for the inclusion of these passages into the corpus propheticum.

15 Other divisions of the book are under discussion, e.g. between Joel 1:2-2:17 and 2:18 - 4:21 (Engl. 3:21). Cf. Erich Zenger, Einleitung in das Alte Testament (Stuttgart: Kohlhammer, 1995), 381-85. More important is Zenger's evaluation of the booklet as mere "literary prophecy and prophetic interpretation of prophetic writings... probably written to be placed into its present position in the Book of the Twelve" (383). Cf. James D. Nogalski, Redactional Processes in the Book of the Twelve (BZAW 218; Berlin: de Gruyter, 1993), 3-57. Determining the literary origin, however, does not solve the question of the Sitz, because literary texts may have been used in worship. 
scholars consider this part of the book its authentic nucleus, declaring the subsequent passages as later accretions. The first two chapters of Joel contain elements of communal complaint ${ }^{16}$ and responses by Yahweh. Many exegetes regard Joel $1-2$ a full-fledged worship liturgy motivated by a locust plague or some other public calamity. ${ }^{17}$ In fact, most interpreters think of some liturgical provenance for the text. The question remains, however, how such a special genre could possibly enter the prophetic canon to begin with. According to traditional presuppositions the prophet must enter the temple sphere and become a cultic functionary in order to make plausible the existence of a whole cluster of liturgical-agendaric genres in the prophetic collections, presumably consisting of freely communicated messages of Yahweh. The opposite view may be closer to ancient Israel's reality, but still misses the point by a wide margin. It claims that the prophet did not need to enter the cultic realm. Rather, the ideal figure of a communicator of Yahweh's word and will to the early Jewish congregation emerged from cultic practice, because that word had been synthesized right in the midst of the community's anxieties and hopes.

In Joel $1-2$ we have an agendaric block of material to which, in the course of worship, other liturgical passages (Joel $3-4$ ) have been added. (A similar relationship seems to prevail regarding Micah 7 and the preceding chapters of the book). At first glance it appears as if a liturgical block has been placed at the end of a collection of prophetic sayings. ${ }^{18}$ For what purpose? Why would the composers of the book choose liturgical forms to conclude a written composition? And why, for that matter, did they occasionally use prayer language when shaping the body of the text (cf. Mic 1:8$16 ; 4: 5 ; 5: 4-5 ; 5: 8 ; 6: 6-8)$ ? Would it not be more reasonable to image the reverse of this procedure, namely that prophetic sayings, in oral or written

"The liturgical character of these texts indicates that the prophetic books of which they are a part were read as part of the temple liturgy." Cf. Marvin A. Sweeney, Isaiah 139 (FOTL XVI; Grand Rapids: Eerdmans, 1996) 17.

16 As to the terms used here for genres - especially "complaint," "lament," "divine response." etc., cf. Erhard S. Gerstenberger, Psalms, Part I (FOTL XIV; Grand Rapids: Eerdmans, 1988) esp. 10-14; and Psalms, Part II (FOTL XV; Grand Rapids: Eerdmans, 2001) 506-543 (Glossary of genre terms).

17 Cf. Gösta W. Ahlström, Joel and the Temple Cult of Jerusalem (VTSup 21; Leiden: Brill, 1971); Oskar Loretz, Regenritual und Jahwetag im Joelbuch (Altenberge: Ugarit Verlag, 1986).

18 Ever since Hermann Gunkel ("Der Micha - Schluss", $Z K 2$ [1924] 145-178) exposed the liturgical character of this final chapter of Micah, scholars have speculated about the genre and function of these verses (Mic 7:8-20). There is a certain agreement on the basic forms being "agendaric," but many colleagues shun away from calling them "real liturgical texts." They think rather of literary imitations (cf. Rainer Kessler, Micha [HTKAT, Freiburg: Herder 1999], 296-312). 
transmission, had been drawn into and molded by community services of exiled congregations. ${ }^{19}$ Had these Yahwists fashioned prophetic sayings, just as early Christians incorporated and developed the words of Jesus in their texts?

Another example of sorts, again slightly different from the preceding two, is Nah 1:1-11. Clearly, there once was an alphabetical acrostic somewhere within or without the book of Nahum, parts of which have been preserved in Nah 1:2-8. Its lines successively begin, with some errors and omissions, with the letters Aleph to Kaph of the Hebrew alphabet. Equally clear is the fact that the text of an acrostic poem has been severely remodeled, perhaps to fit into the congregational philosophy and the liturgical practice of the ancient assembly. The enemies directly addressed (Nah $2-$ 3) will suffer defeat from Yahweh's retaliating onslaught, and implicitly Israel will be liberated from her foes. This in all likelihood is the subject of liturgical celebrations, and the vividness of language and metaphors contributes to create this very impression. ${ }^{20}$

\section{Psalms Reacting to Prophetic Speeches}

A larger number of psalmic passages have been tightly interwoven with the regular "prophetic" contexts. ${ }^{21}$ Apparently, they react to messenger speeches or prophetic denunciations of Judah or Israel. A good example is Hos 6:1-6. The preceding lines (Hos 5:8-14) are a terrible invective against the cities and tribes of northern Israel, conjuring - in military and accusa-

19 Ehud Ben Zvi in his commentary Micah (FOTL XXIB; Grand Rapids: Eerdmans, $2000[3-11 ; 171-72 ; 181-82])$ ) emphasizes individual and communitarian reading of the written text. The "bearers" of this communicative office was a "circle of literati ... of high literacy in their society, and who took the role of brokers of the knowledge imparted by the book of Micah..." (181 and often). I do not see a reading culture in ancient Judah as early as the late Persian period. Rather, the texts in their dramatic orientation, preserved in the written sources, testify to authentic liturgical proceedings.

20 Michael H. Floyd (Minor Prophets [FOTL XXII; Grand Rapids: Eerdmans, 2000], 1020 ) decidedly rejects the idea of Nahum's being "an extended eschatological hymn" or "a prophetic liturgy," but he faces serious difficulties in explaining the vivid direct address discourse throughout the book as "resembling those [i.e. rhetorical conventions] that are home in some kind of ritual or ceremonial context ..." (12, cf. 15-18). "Although the conventions of direct address used in Nahum are somewhat similar to ones that might also be used in a ritual setting, they neither entail ritual acts nor reflect a cultic tableau" (17). His solution, then, is to locate the literary prophet in groups of scribes and wise men who "wrote books like Nahum to be studied among themselves, and to be used for the instruction of public officials and others ..." (19). For the book of Habakkuk, however, he partially admits cultic use $(85,87$; etc.).

21 Cf. Aaron Schart, Die Entstehung des Zwölfprophetenbuches (BZAW 260; Berlin: de Gruyter, 1998). 
tory terminology - an enemy invasion. The diatribe culminates in a divine pronouncement of destruction and deportation (Hos 5:14b-15): ${ }^{22}$

\author{
I myself will tear and go away; \\ I will carry off, and no one shall rescue. \\ I will return again to my place \\ until they acknowledge their guilt and seek my face. \\ In their distress they will beg my favor.
}

Thus the severe announcement of divine castigation ends up in giving the catchword for the following communal confession of guilt and declaration of confidence, ${ }^{23}$ forms well known from collective complaints (to Hos 6:1-6 compare e.g. Pss 95:6-7; 100; 106:6; Neh 9:16-31; Ezra 9:9-15; Dan 9:5-16 etc.). The communal complaint of Hos 6:1-6, therefore, is an integral part of the prophetic text, and it makes the unit Hos 5:8 - 6:6 a true reflection of communal worship.

The same holds true or else may be reasonably claimed, e.g. for Zeph 3:14-15: ${ }^{24}$ Hab 1:2-4, 12-14; Mic 4:1-5 (parallel to Isa 2:1-5); 6:6-8; and other passages. Even dirge-like poems, e.g. in Mic 1:8-16; ${ }^{25}$ Amos 5:1-3, may have to be reevaluated under the hypothetical perspective of being an authentic witness of some sort of communal or perhaps individual (i.e. small group $^{26}$ ) worship. This kind of intimate relationship between psalmlike passages and "prophetic" pronouncements can hardly be explained by any theories about cultic prophecy. Hans Walter Wolff may have come pretty close to the truth when summing up his observations as to the liturgical qualities of Mic 7:8-20:

22 Analytical details can be found in Hans Walter Wolff, Hosea $\left(2^{\text {nd }}\right.$ ed.; BKAT XIV $/ 1$; Neukirchen-Vluyn: Neukirchener Verlag, 1965) 131-167; Jörg Jeremias, Der Prophet Hosea (ATD 24/1; Göttingen: Vandenhoeck, 1983), 78-83.

23 Wolff (Hosea, 1.48-49) calls it a "song of penitence" (Busslied).

24 Cf. Erhard S. Gerstenberger, "Der Hymnus der Befreiung im Zefanjabuch," in Walter Dietrich et. al. (eds.), Der Tag wird kommen (SBS 170; Stuttgart: Katholisches Bibelwerk, 1996), 102-12.

25 Cf. Kessler, Micha, 90-111.

26 We should resolutely move away from the unilateral idea that worship in exilic/postexilic times had consisted only in temple ceremonies, animal sacrifice and occasional pilgrimages to Jerusalem. There were manifold rites and rituals even under the influence of exclusivistic thinking in terms of monotheism. Cf. Erhard S. Gerstenberger, Der bittende Mensch (WMANT 51; Neukirchen-Vluyn: Neukirchener Verlag, 1980); Yahweh the Patriarch (Minneapolis: Augsburg Fortress, 1996), 55-66; and Theologien im Alten Testament (Stuttgart: Kohlhammer, 2001). The English translation is Theologies in the Old Testament (Minneapolis: Fortress; and Edinburgh: T\&T Clark, 2002). 
Relevant worship services comprised in the first place readings of old prophetic sayings announcing the evil ..., secondly contemporary prophetic utterances highlighting the actual situation by biting critiques or comforting words ..., and finally the psalm-like response of the congregation, referring to the preceding kerygma. ${ }^{27}$

\section{Psalms with no Apparent Connection with Their Context}

Only a very few relevant psalm-like texts seem to have been included in prophetic books, like erratic pieces of non-prophetic origin, or meteor-like material witnesses of another world. Closer investigation still may yield contextual ligatures, though. The items most frequently discussed over an extended period of time are those fragmented parts (?) of Yahweh hymns found in the book of Amos (4:13; 5:8-9; 9:5-6; [Amos 8:8?]), the so-called doxological intrusions. They indeed have long puzzled exegetes, precisely for being so disconnected with their context. ${ }^{28} \mathrm{Be}$ that as it may, the inclusion of seemingly disconnected hymnic elements may constitute more evidence for the possible cultic origin and use of "prophetic" books. In an orderly written theological treatise, sudden hymnic exclamations hardly seem to fit.

\section{Conclusions}

\section{A. The Role and Setting of Psalmic Texts in the Prophets}

Psalmic texts are integrated into the Book of the Twelve in a variety of ways. We have to describe the modalities and functions these passages or literary units are performing in their respective contexts. A frame of introductory and/or concluding formulas in the fashion of Psalm superscriptions suggests the availability of the text for liturgical ends. Such redactional superscriptions are no mere literary dressing without meaning for the reader.

27 Hans Walter Wolff, Micha (BKAT XIV/4; Neukirchen-Vluyn: Neukirchener Verlag, 1982), 194.

28

Perhaps Karl Budde ("Zur Geschichte des Buches Amos," BZAW 27 [1914] 63-77) was the first to focus on this phenomenon. Friedrich Horst ("Die Doxologien im Amosbuch," ZAW 47 [1929] 45-54) gave the first comprehensive treatment of the form. To him doxologies are customary responses of those accused of crimes. They have to admit their guilt, so that they may be sentenced. Cf. also Werner H. Schmidt, "Die deuteronomistische Redaktion des Amosbuches," ZAW 77 (1965) 168-73; Werner Berg, Die sogenannten Hymnenfragmente im Amosbuch (Frankfurt: Bernhard Lang, 1974); Klaus Koch, "Die Rolle der hymnischen Abschnitte in der Komposition des AmosBuches," ZAW 86 (1974) 504-37. Koch rejects Horst's interpretation, arguing instead for each hymnic fragment's being a marker of a book division, which actually points back to some liturgical use of the texts (536). James L. Crenshaw (Hymnic Affirmation of Divine Justice [SBLDS 24; Missoula: Scholars Press, 1985] develops further Horst's position. 
Instead, they contain real information about the use of the text in communal ceremonies, about which we may understand little from our historical distance. Unframed, semi-autonomous psalmic texts may be equally convenient pieces for worship services of the community. For a psalm-like text marked as in Habakkuk 3 and for most poems of the Psalter, one is hard pressed to imagine another than a liturgical purpose. Superscriptions consisting of personal ascriptions and technical terms hardly serve the interests of individual readers. ${ }^{29}$

Communicative and interactive uses of psalmic texts in "prophetic" writings may hint at the possibility that it was not the prophetic texts that attracted liturgical elements. Instead, cultic situations may have produced prophetic pronouncements and literature. At least, it seems to me, all the traditional theories of (a) the authentic, historical men of God in the name of Yahweh creating collections of oracles and proclamations, and (b) such collections migrating into the cultic memory are much less plausible. How and why would the voices of autonomous communicators of Yahweh's will, addressing themselves to very concrete and transient contemporary problems, be preserved over the centuries? It is much easier to imagine communities which - experiencing the pressures of the exilic/post-exilic age looked backwards to find some explanation and orientation for their daily lives under the rule of Yahweh. They wanted to understand their destiny at the hands of Babylonians and Persians. They knew or invented prophetic figures in the past that should have known beforehand the plans of God for his people, the fate of the monarchy, and the spiritual uncertainties in a very pluralistic and hostile world. So whatever little information still was available of Isaiah, Jeremiah, Ezekiel and the Twelve would be brought into the assemblies, discussed and actualized there. The processes of collecting traditions of the past, of joining their bits of the "prophetic" heritage together, of actualizing the older sayings and exhortations by creating new "prophetic" proclamation were all interwoven as part and parcel of the same gradual compilation of the prophetic canon.

Only the erratic variety of willfully interspersed psalms or fragments of psalms in an apparently psalm resistant context could cause problems for our present tentative of interpretation. Why should later redactors place such texts into an alien context like "prophetic" discourse? The best explanation, it seems to me, is the real worship situation in exilic and post-exilic Judah (or Diaspora, for that matter). Perhaps congregations would respond

29 To regard the Psalter (and the Prophets?) as private reading material has come into vogue in the past years. It seems to me, however, that the underlying concepts of writing and reading presuppose a modern literary society, which does not even exist in all countries of our world today. Investigations, e.g. in Latin America, show that less than $10 \%$ of the population read regularly. 
to brutal announcements of doom by intoning hymns or staging complaint services. Hymn singing, in fact, can be a weapon against destruction and misery. Eulogizing the supreme power of God, the mighty benevolence of the Creator and Protector, all by itself may defeat the hateful powers or evil potencies. Thus, the Chronicler tells of military victory on account of hymn singing (2 Chron 20:21-22). And the legendary witnesses of Yahweh in Daniel 3, according to the Greek apocryphal tradition sing hymns in the midst of the "fire oven." Furthermore, hymnic passages may constitute part of complaint songs. ${ }^{30}$ For these reasons the fragmented hymn of Amos should not seem too strange to us. On the contrary, it could be another piece of evidence for the origin and transmission of prophetic preaching, which solicits from the beginning communal response and participation.

\section{B. Reading Texts in Post-exilic Judah}

Textual analysis alone will not solve the enigmas in regard to prophetic tradition and prophetic office. Readers of ancient texts will always bring with them culturally acquired paradigms of ancient reality, which serve as background and matrix for the interpretation of individual texts. Thus our general ideas of what prophecy and prophetic tradition was like will determine to a large extent the results of our exegetical endeavors. As indicated at the beginning of this paper there are numerous basic issues to be critically evaluated before we come to grips with the psalmic passages in the Book of the Twelve. Here are some of the underlying questions. What has been the significance of putting prophetic proclamation into writing? Millions of words of different mediators between God and humans certainly have not been preserved in any kind of document. Why and to which end were some of them frozen into letters? How have the emerging written collections been used? Has there been already in Persian times a culture of reading books for private edification? If so, which parts of society were able to indulge in the luxury of buying and reading written documents? On the other hand, how can we visualize communities cultivating their own traditions in written form? The era of public libraries evidently began only in the Hellenistic period. ${ }^{31}$ What kind of experts did they need to handle the written records? Quite naturally, learned scribes were highly important, but also theologians and spiritual leaders of sorts who determined the quality and authenticity of the written words. ${ }^{32}$

30 Cf. Gerstenberger, Psalms, Part One, 11-14.

31 Cf. Philip R. Davies, Scribes and Schools (Louisville: Westminster John Knox, 1998), 74-88; 107-25. 8

32 Cf. Joseph Blenkinsopp, Sage, Priest, Prophet (Louisville: Westminster John Knox, 1995). 
Of these the most critical issue is this: what was the purpose of the written tradition, on the one hand for the torah of Moses, and on the other hand for the emerging prophetic canon? Can we claim the written word was destined principally for public recitation as in Neh 8:2-3 and - reduced to the royal court - Jer 36:4-26? If that has been the case, how much influence is to be attributed to the community of recipients of the words of God? In analogy to the "Gemeindebildung" (formulation of kerygma by the congregation) in New Testament times, the authorship of "prophetic" words to a large extent may be located in that living process of communal expectation and the shaping of contemporary (early Jewish) liturgical agendas promoted by the scribal and theological elite. Thus, considerable parts of the prophetic "books" prove to be retro-projected compositions of the late community, rather than the "classical" prophetic authors mentioned in the superscriptions. ${ }^{33}$

If this assumption is plausible, we have to investigate primarily the living conditions, theological outlooks and communitarian practices of the early Jewish community of the Persian epoch in order to understand correctly prophetic "books" and "writings." The life setting of prophetic words and psalms would not be "the book" as is sometimes erroneously claimed. Rather, written records of the congregations of believers in Yahweh in Persian times (beginning, as it were, under the dominance of the Babylonians) point to various worshipping rites in which written words were used, recited either from memory or by open and public reading. The people "told the scribe Ezra to bring the book of the law of Moses ... he read from it ... from

33 The facts are quite obvious in case of the book of Isaiah. Cf. e.g. Otto Kaiser, Das Buch des Propheten Jesaja Kapitel 1-2 (ATD 17; Göttingen: Vandenhœck \& Ruprecht, 1963); Uwe Becker, Jesaja - von der Botschaft zum Buch (FRLANT 178, Göttingen: Vandenhoeck, 1997). The facts are also clear for Jeremiah. Cf. e.g. Robert P. Carroll, Jeremiah. A Commentary (OTL, London: SCM Press, 1989); Winfried Thiel, Die deuteronomistische Redaktion von Jer 1-25/von Jer 26-45 (WMANT 41 and 51: Neukirchen: Neukirchener Verlag, 1973 / 1981); Karl-Friedrich Pohlmann, Die Ferne Gottes (BZAW 179; Berlin: de Gruyter, 1989). On Ezekiel, cf. e.g. Johan Lust (ed.), Ezekiel and His Book (BETL 74; Leuven: University Press, 1986); Bernhard Lang, Ezechiel, Der Prophet und das Buch (Darmstadt: Wissenschaftliche Buchgesellschaft, 1981). For Amos, cf. Werner H. Schmidt, "Die deuteronomistische Redaktion des Amosbuches," ZAW 77 (1965) 168 - 193; and Dirk U. Rottzoll, Studien zur Redaktion und Komposition des Amosbuches (BZAW 243; Berlin: de Gruyter, 1996). On Hosea, cf. Hans-Walter Wolff, Hosea $\left(2^{\text {nd }}\right.$ ed.; BKAT XIV/1; Neukirchen: Neukirchen-Vluyn, 1965); Jörg Jeremias, Der Prophet Hosea (ATD 24/1; Göttingen: Vandenhoeck, 1983). On Micah, cf. e.g. Ehud Ben Zvi, Micah (FOTL XXIB; Grand Rapids: Eerdmans, 2000); Kessler, Micha. It is strange, indeed, that many exegetes still ignore the facts and start their investigations from the alleged fountainhead, the historical prophet himself, instead of working backwards from the most productive, later communities towards earlier layers of tradition. 
early morning until midday ..." (Neh $8: 1,3)$. "Baruch wrote on a scroll at Jeremiah's dictation ...", "you shall read the words of the Lord from the scroll that you have written at my dictation." (Jer 36:4, 6). "When Hilkiah gave the book to Shaphan he read it. ...Shaphan then read it aloud to the King." (2 Kings 22:8, 10). Moses "took the book of the covenant, and read it in the hearing of the people." (Exod 24:7). He "commanded them: Every seventh year ... you shall read this torah before Israel in their hearing." (Deut 31:10-11). Joshua "read all the words of the torah, blessings and curses, according to all that is written in the book of the torah." (Josh 8:34). There are a good number of Deuteronomistic passages hinting at the written precepts of Yahweh put down by Moses and communicated by him. All of these references may be understood as reflections of exilic/post-exilic habits of reading aloud the words of Yahweh to the assembled congregation. This also implies that where we hear of "reading the Word" in Hebrew Scriptures it is public recitation, not private musing (except in Deut 17:18; Ps 1:2?) The recitation of Scripture by itself becomes a liturgical act, a scenario with the essential ingredients of authorized reader, scroll of torah, listening and responding community (which, by the way orders the scroll to be brought into the assembly; cf. Neh 8:1).

\section{Post-exilic Worship as the Sitz im Leben of Prophetic Literature}

Returning to the issue of psalms in the Twelve we may say that most scholars probably agree that the bulk of "psalmic" passages in the prophetic canon (and particularly in the Book of the Twelve) does have some affinity to liturgical texts and outlooks. Few, however, will accept the idea that these cultic elements may be the "Leitfossil" of the whole prophetic literature and especially the Book of the Twelve. I should like to argue that way. The psalm-like parts may betray the formative matrix at least for the compilation of the Book of the Twelve, and beyond this general frame they may hint at the enormously creative "Sitz im Leben" that brought forth a considerable part of retrospective "prophetic" proclamation and other divinely inspired discourse. Unfortunately, we do not have much direct, authentic information about the early Jewish communities and their leadership as being active in writing prophecies under the disguise of Isaiah, Jeremiah, Ezekiel and the Twelve. But all the Hebrew prophetic writings in their formative phases have been, as pointed out above, quite susceptible of becoming car-

34 Cf. F. L. Hossfeld and H. Lamberty-Zielinski, " $q r$ '," ThWAT 7,133-36: "The meaning "to read" for $q r$ ' is attested only from the exilic period onward ...." (134). "[P]ublic reading as part of covenant making acquired a cultic character..." (135); F. L. Hossfeld and E. Reuter, "seper," ThWAT 5,932 - 944. 
riers of contemporary theology and preaching. It is only from this perspective that prophetic books as a whole become really understandable.

Prophetic speech in this regard becomes solidly grounded in community worship without the "classical" prophets becoming cultic functionaries. An additional, thorough investigation of speech forms (i.e. taking seriously congregational involvement in the production of prophetic books) in the Twelve and the bigger Three - I am thinking in particular of the frequent genres of "admonition" or "exhortation," "call for repentance," "ethical reflection," etc. - would without doubt greatly enhance the quest for a primarily cultic origin of "prophetic" compositions and discourses. There are some indications in the Hebrew canon itself that such a model of "prophecy" comes close to ancient reality.

We should e.g. reconsider the famous relationship of Jeremiah to his personal scribe Baruch under this angle. Ancient "prophetic" words and figures in fact need to be transmitted to posterity by mediation of "scribes." Classical prophets did not write down their messages. Nor were they called nabi' for that matter (cf. 1 Sam 9:9). Baruch wrote down the words of God communicated to Jeremiah and read them to the congregation, like court officials read the "prophetic" work to the king (cf. Jer 36). This beautiful and theologically most meaningful story, made up in Deuteronomistic circles, clearly depicts the mediation of the Word through written documentation. The "words of Jeremiah" are put down faithfully to be recited to the people, so that it can "amend its ways and its doings" (cf. Jer 7:3). Mediation through letters and literature is important. Therefore, the prophet is seen barred from the temple, in order that his (later) representative may communicate with the congregation. The destruction of the written Word is the imminent danger, not the possible demise of the prophet himself. Even the mediators of the Word of Jeremiah step into the background. The victorious writings prevail; they are victorious. The king may burn the first scroll, a new, enlarged edition will appear immediately at Jeremiah's dictation, containing all the speeches destroyed before, "and many similar words were added to them" (Jer 36:32). Of course, there is no explicit admission, that the mediators themselves enlarged some original collection of prophetic sayings. But everyone understanding the human genesis of sacred writings, and everyone who thoughtfully and attentatively reads our "prophetic" books in the Hebrew Bible should be able to recognize the growth of prophetic traditions. And the psalmic components indeed may lead us to the sources of prophecy and nabi'-hood: the proper community of faith struggling with its own past and for its identity and survival in turbulent times. 


\section{Hymns as Indicators of the Communal Authorship of the Prophets}

With good evidence at hand of (a) the growth and shaping of "prophetic" traditions to have taken place in exilic/post-exilic times and (b) the unifying concept of Yahweh having sent in vain a whole series of prophets for the sake of his people to be a late systematization, we may finally compare the two approaches to prophetic literature, bearing in mind the lead of the psalmic passages in the Book of the Twelve.

The interpretation of prophetic texts in the past tried to start out from the historical person who communicated the will and verdict of Yahweh to his people in concrete historical moments of the life of Israel. Mentally starting from this point zero, the point of origin of individual texts, normally short sayings, modern exegetes tried to identify authentic messages and later, consecutive additions or modifications of these more or less divine words. Eventually, the main interpretative effort having cleared the very fountainhead of prophetic activity, the various layers of subsequent interpretations and comments had to be analyzed and explained, down to the Masoretic fixation of the Hebrew writings and the ancient versions as well as on through posterior theological debates in Jewish and Christian history of interpretation. A complete exegesis of a given text would include, therefore, a painstaking scrutiny of its first utterance as well as of its subsequent reworkings, alterations in diction and meaning. If later additions, corrections, etc. had overgrown the original "prophetic" word, the modern interpreter would have to muster his or her sharp tools of historical-critical and formand social-critical research and cut back through the jungle of later interpretations in order to get to the fountainhead of that overarchingly significant first saying and its author.

The presence of psalm-like texts in the prophetic canon, which may point to the late, community-bound matrix of all "prophetic" texts, alerts us to the possibility of a very different approach. What we do have in the Hebrew prophetic books, especially in the Twelve, are pieces of literature probably going back to the fifth and fourth centuries B.C.E. We would have to take seriously the final shape and the late origin of these "prophetic" writings. First, the final literary product would have to be analyzed, including a probe into the social, cultural, theological conditions under which the book or writing came about. The creative interests prevalent in the group which used a given prophetic book or compilation have to be investigated. No human being and no group of people can avoid, while designing for him- or itself relevant pictures of the past, to impose his/its own, contemporary experiences on the older witnesses or interweave the bygone testimony with actual patterns of thinking and acting. This insight of everyone constructing the world in his or her own likeness is valid for biblical writers as 
well as for modern exegetes. In the case of the biblical tradition, the images of prophets and their messages as preserved in the Book of the Twelve to a very large extent are condensations of prophetic types and roles, known and/or invented exactly in the period under discussion. Having established the profiles of the youngest layer of tradition in the final written "prophetic" document, we would go upstream in order to recognize more clearly the historical depths of "prophetic" transmissions. Who knows whether one day we may come to discover or reconstruct one or two authentic words of some historical prophetic figure? In the case of the Twelve it seems obvious that we hardly encounter any trustworthy information about the eponyms of those booklets which carry their names.

Are the psalmic passages, then, misplaced in the Book of the Twelve? I trust that this is not the case. On the contrary, the psalm-like parts are not inserts at all in the fourth collection of "prophetic" words. They are treasures of prayers and hymns all testifying to a vivid Israelite community life in Persian times; and they open our eyes as to the wondrous world of preaching, teaching, debating theology, which must have gone on in many congregations of Yahwists within the small province of Judah as well as in Diaspora situations abroad. 